\title{
Role of Multinational Companies (MNE) in the Transfer of Human Resource Management (HRM) Practices in Albania
}

\author{
Alba Berberi (Mirashi) \\ Department of Business-Administration, Faculty of Economy, University of Shkodra "Luigj Gurakuqi" \\ Albania; berberi_al@hotmail.com
}

\author{
Ahmet Ceni \\ Department of Management, Faculty of Econony, University of Tirana, Albania
}

\section{Doi:10.5901/ajis.2015.v4n3s1p445}

\section{Abstract}

\begin{abstract}
Globalization is part of everyday life for everybody and for companies, too. In this globalization era, multinational companies (MNE) are gaining new experiences in diverse environments, diverse nations and diverse cultures. So, a big concern for MNEs, nowadays, is the issue of convergence versus divergence. In the focus of this issue is the transfer of Human Resource Management (HRM) practices across countries. The effectiveness of this transfer is the key of success of MNEs and it depends on different factors, such as: the cultural distance between MNEs home country and host country; new institutional environments; presence of expatriates in their subsidiaries etc. This paper is a literature review one and has in focus the identification of factors affecting the transfer of HRM practices from MNEs in their subsidiaries in Albania. In the Albanian reality there is a lack of studies in this aspect, which serves as the contribution of this topic, same as for academics, as well as for MNEs that have subsidiaries in our country. The future research will continue with survey method which tends to collect data from the top managers of subsidiaries of MNEs operating in Albania.
\end{abstract}

Keywords: globalization, multinational companies, HRM practices, Albania.

\section{Introduction}

Nowadays, companies are facing a more competitive environment due to globalization. Globalization has accelerated not only the transfer of products and services, but also the transfer of managerial practices, including HRM (Human Resource Management) practices. MNEs (Multinational Enterprises) are a powerful operator in the transfer of capital, managerial and technical knowledge between nations (Tayeb, 1998).

According to Harvey et.al, (2001), the role of human resources is even more important now that companies expand their activities in different countries. This is especially true in the case of MNE's, where the effective management of these resources can be a key factor for success or failure (Tung, 1987). Effective transfer of HRM practices, which can be difficult to imitate by competitors, is perceived as the key to success of MNE's in the 21th century. In the same subsidiary of a MNE, some management practices may remain the same as those of the parent company, while other practices may change and adapt to those of the host country. It could be argued that cultural and institutional environment, as well as other factors, have a decisive importance for the transfer of HRM practices in host countries.

\section{An Overview of MNEs}

The globalization of the economy means an increase in economic activity between countries. The importance of MNEs is increased due to the globalization and the need to achieve a competitive advantage in such a competitive environment.

There are several definitions of a Multinational Enterprise (MNE). According to Ghoshal and Bartlett (1990) define it, as a group of geographically dispersed organizations that include its headquarters and the different national subsidiaries. According to Caves (1996), defines it as an entity that controls and manages production establishments in at least two countries; according to Dunning (1993) defines a MNE as "an enterprise that engages in Foreign Direct Investments (FDI) and owns and controls value adding activities in more than one country"; and so continuing, there are definitions of MNEs second different authors and researchers on this field.

According to Bartlett and Ghoshal (1998), the evolution of MNEs can be divided in four periods: multidomestic 
period (1920-1950), when- MNEs set up a large number of foreign manufacturing subsidiaries that are independent from their headquarters, this is for the reason to be able to compete due to high tariffs. International period (1950-1960), whena need for new technologies and products pushed especially American MNEs to have Foreign Investments in Western Europe and developing countries. Global period (1960-1980), when- decrease protectionist policies, decrease costs transportation, communication improvement and manufacturing technologies made it possible for MNEs to have profitable export and Foreign Investment of centralized and standardized production and transnational period (19802000), when- increased recognition of difficulties linked to geographically spread made MNEs more respondent to the needs for global efficiency balanced with national responsiveness.

MNEs operate today in various sectors of the economy, manufacturing industries, the mining industry and the oil, agriculture, as well as in the service sector (Eitman et al., 2004). They have opened their subsidiaries in foreign countries to develop more diverse activities, from providing research and development services and after sales services to production or insertion of different products.

So, what are the reasons why many firms become multinational? Ferdows (1997), Madura (2002) and Eitman et al. $(2004,2007)$ linking the creation and existence of multinational companies with the need to increase sales in foreign markets and the need to provide inputs such as raw materials and the workforce, with lower cost. Likewise, according to Ferdows (1997) and Madura (2002) many firms expand a portion of their production activities in other countries in order to avoid tariff barriers that hinder the export of products in these markets, and in order to react and distribute risk arising from changes in exchange rates. An equally important reason is the possibility that multinational companies to provide additional technical and managerial knowledge from suppliers, customers, competitors and research centers in foreign markets (Ferdows, 1997; Eitman, 2004; 2007).

Strategic management of international human resources is becoming more and more a crucial factor for the future prospects of MNEs, as much as their activities globalizing (Harvey et al., 2001). Human resource management in an international context represents a more complex process, due to the differences between business environments in different countries where it has spread a certain company. This process involves the recruitment, selection, training, development, evaluation and compensation of employees, as well as establishing good relations with them.

\section{Trends of Globalization and their Impact on the Albanian Economy}

International trade and foreign direct investment constitute the two main forms of globalization in the economy. The liberalization of the latter led to overcome quite a few barriers in trade and capital movements, associated with the development of foreign trade and attracting increased foreign direct investment. As a result of this phenomenon, today in the Albanian economy several hundred companies have been settled with foreign capital, which for many years work in our country (Uruçi \& Boriçi, 2008). In the framework of efforts to become part of the global market and also a member of the European Union (EU), since 2000 Albania has entered the World Trade Organization (WTO) and has signed the Stabilization and Association Agreement with The European Union, an agreement which entered into force on 1 December 2006. This agreement provides for the gradual liberalization of tariffs for products imported from countries of the European Union (EU), the process that meets fully the end of 2011, and removal of tariffs for almost all Albanian products that are exported to EU countries, with the exception of a limited category of agricultural and industrial products.

\subsection{Foreign Trade}

A very important factor that affects the growth of a country and reflects the increasing competitiveness is also its foreign trade. Albania applies a liberal trading system, which, according to a decision of the Council of Ministers in 1998, guarantees an open regime of import-export, with the exception of certain goods such as military and strategic goods, radioactive materials, which are subject to the same regulations as the international ones. Exports are not subject to any taxes or other barriers to the same effect, while imports only apply customs duties. Albania's membership in the WTO, the signing of the Stabilization and Association Agreement with the EU, as well as its participation in the CEFTA 2006 represented the major efforts of the Albanian state to further liberalization of foreign trade, thus increasing the participation of our country to global markets.

\subsection{Foreign direct investments in Albania}

The phenomenon of globalization of economic activities has become a key factor in promoting direct foreign investments. 
They were very big changes in trade policies through liberalization and tariff reduction, acquisition and privatization of some industries of various countries, which have served as the most important catalysts for expanding the role of foreign direct investment (Uruçi \& Boriçi, 2008). According to a common definition of the International Monetary Fund and the Organization for Economic Cooperation and Development, "Foreign Direct Investment (FDI) are meant to secure a longterm interest of a resident entity in one economy (foreign investor) in an undertaking that is resident in another economy "(Bank of Albania, Economic Bulletin, 2006). FDI occupy an important position in the economy of a country. They are associated with a variety of positive effects on the host countries, such as a sudden increase in the productivity of enterprises purchased by foreign investors, technology transfer, human capital development and creating a more competitive business environment in these countries.

\section{Transfer of HRM Practices}

Nowadays it seems very important to study the transfer of HRM Practices from MNEs to their overseas subsidiary. MNEs are a powerful tool for knowledge transfer and technical management, capital and other production functions between countries. The whole process is part of their overall strategy. Generally, MNEs have three strategic HRM options to choose from: ethnocentric, polycentric and global (Perlmutter, 1969).

An ethnocentric strategy is one in which the company chooses to implement policies and practices of HRM similar to those of the originating country in its affiliates. When a company mainly pursue policies and practices that can find in the host country; then it's choosing a polycentric strategy. In case it chooses global strategy, the company will develop and implement a universal policy, which "feeds" from its culture and organizational philosophy, regardless of where it occurs.

As organizations in developing countries and industrialized countries have different external environments, the transfer of management theories and practices from one country to another, may have limited applicability (Kanungo \& Jaeger, 1990). This is why, "the transfer of management theories and techniques based on Western ideologies and value systems have contributed in many ways to organizational inefficiency and ineffectiveness in the context of a developing country." (Kanungo \& Jaeger, 1990)

Since in most cases the organizations are formed within a particular country, their ways of working are strongly influenced by the culture of that country (Hofstede 1980; Laurent 1983; Schneider 1988; Trompenaars 1993). Practically, there is no aspect of management that is completely unaffected by culture and extensive research shows that cultural differences are an important cause of divergence in management practices worldwide. Another more descriptive point of view about the international HRM is offered by Teagarden and Von Glinow (1997), who argued that many HRM practices are specific to particular cultures and cannot be generalized.

Kostova (1999) also proposes that transfer between different business systems is influenced by "institutional distance" (i.e. the difference between "institutional profile" of MNEs country of origin and the host country in which it operates), or as Silverthorne (2005), suggests, HRM practices in many countries are also affected by the rules that govern business. In summary, the HRM practices in a given country tend to be influenced by both; cultural and institutional arrangements (Leat \& El-Kot, 2007).

Another study that identifies the factors affecting the transfer of HRM practices is that of Beechler and Yang (1994), who argued that there are three groups of factors that influence whether a multinational company wants or can transfer its HRM practices in subsidiaries thereof. These are, first of all, the factors associated with the origin country, like the culture of the home country of the MNE. Secondly, factors associated with the host country, such as: culture and its distance from the culture of MNEs home country, labor market conditions and industry practice rules. Thirdly, the factors associated with the company itself, such as: to what extent MNE's subsidiaries are an integral part of the parent company's strategic plans and the degree to which the parent company is dependent on its affiliates to provide resources required. Keller (1989) suggested that it is easier to transfer the technical parts of management than those parts that directly affect employees.

Another factor in determining and implementing global practices in HRM national level is the presence of foreign managers in subsidiaries of MNEs. Indeed, the presence of foreign managers has increased the similarity of HRM practices between MNEs subsidiary and parent company (Rosenzweig \& Nohra, 1994) and thus encouraging, greater adherence to the guidelines set by MNEs. In addition, foreign managers also have the communicative role within the subsidiary in the host countries and serve "to transfer their knowledge and managerial skills in subsidiaries of the host countries", orienting, so local employees to a favorite work style (Gamble, 2003).

Choosing HRM strategy by MNE depends on how the foreign subsidiary is set up. If it is set up as a green field, 
managers transferred to the subsidiary have more room to exercise their choices on HRM practices that they use; but, if the subsidiary is established by acquisition an existing local company, the new company is more likely to resemble other firms in the country (Tayeb, 1998).

Other studies aim to see the impact of the size of the subsidiary in the transfer of HRM practices. We cannot accurately determine from these studies the impact of the size of the subsidiary in the transfer of HRM practices because, on the one hand, major subsidiaries may seek employment to a significant number of workers from the host country, which may make it difficult to transfer HRM practices; on the other hand, major subsidiaries may perhaps depend on resources from the parent company, which may make it easier to transfer HRM practices (Rosenzweig and Nohra, 1994).

Another factor affecting the transfer of HRM practices is the influence of the parent company which may be stronger at the beginning of the activity of the subsidiary, but can be expected to diminish over time and thus affiliates will begin increasingly to resemble the local environment (Rosenzweig and Nohra, 1994). Thus, it is intended to review the impact of the age of the subsidiary in the transfer of HRM practices.

\section{Proposed Methodology}

Reviewing literature on the transfer of HRM practices indicates that there is a very extensive literature on this issue, namely, it is important for the study to find ways of collecting and processing information. The methodology used combines primary data with secondary ones.

Secondary data are the result of a review of a wide and contemporary literature on the transfer of HRM practices from MNE's operating in different countries and cultures. In the Albanian reality there is a lack of studies in this aspect, which serves as the contribution of this topic, same as for academics, as well as for MNEs that have subsidiaries in our country. Its contribution will be to identify the factors that may affect the transfer of these practices by parent companies to their subsidiaries in Albania.

While the primary research sought to be achieved through the distribution of questionnaires to affiliates of foreign companies operating in Albania. The questionnaire will be addressed to the high levels of management in these companies to collect the necessary information regarding factors that influence the transfer of HRM practices.

The advantage of using the questionnaire is that quantitative data from statistical relationships between them produce general results about cases in the study (Creswell, 1994). The use of the questionnaire also enables the collection and analysis of quantitative data using descriptive statistics. These data can be used to suggest possible reasons for certain links between variables and to create models of these connections (Saunders et al, 2009). According to Bartunek et al. (1993), there is no superior search method.

\section{Conclusions}

Globalization represents today a phenomenon, whose consequences are involving developed and developing countries. The main forms of economic globalization are: international trade, foreign direct investments (FDI) and the integration of capital market. The increased amount of FDIs is caused by MNEs activity. Even there are different definitions of such firms, they can be considered as companies with activities expanded in more than one country.

The reasons why companies become multinational are: to provide new markets or low labor cost, to provide new technological and managerial knowledge etc.

A key of success for MNEs, as much as their activities globalizing, is the strategic management of international human resources (Harvey et al., 2001). Second Perlmutter (1969), MNEs have three strategic HRM options to choose from: ethnocentric, polycentric and global).

A great concern for MNEs is the transfer of HRM practices across countries and the identification of factors affecting this transfer. There are different studies on this field such as Beechler and Yang (1994), who argued that there are three groups of factors that influence whether a multinational company wants or can transfer its HRM practices in subsidiaries thereof. These are, first of all, the factors associated with the origin country, like the culture of the home country of the MNE. Secondly, factors associated with the host country, such as: culture and its distance from the culture of MNEs home country, labor market conditions and industry practice rules. Thirdly, the factors associated with the company itself, such as: to what extent MNE's subsidiaries are an integral part of the parent company's strategic plans and the degree to which the parent company is dependent on its affiliates to provide resources required.

Other studies tend to focus on the age, size and type of the subsidiary (as a Greenfield investment or an acquisition) and how these factors can affect the transfer of HRM practices. 
This research work represents only the start in the series of studies dedicated to transfer of HRM practices in the subsidiaries in Albania. Other studies in the future may not limit only in the identifications of the factors influencing the transfer of HRM practices from the MNEs in their subsidiaries in Albania, but may also study the impact of this decision on the performance of these companies.

\section{References}

Bank of Albania, (2006), "Economic Bulletin, 2006".

Barlett, C., \& Ghoshal, S., (1998), "Managing Across Borders", London: Hutchinson.

Bartunek, J., Bobko, P., \& Venkatraman, N. (1993). Towards Innovation and Diversity in Management Research Methods. Academy of Management Journal , 6, 1362 - 1373.

Beechler, S. and Yang, J. Z, (1994), "The transfer of Japanese-style management to American Subsidiaries: contingencies, constraints and competencies", Journal of International Business Studies, Vol. 25, Issue 3, pp: 467-491.

Caves, R. (1996), "Multinational Enterprise and Economic Analysis", (2nd ed.). Cambridge: Cambridge University Press.

Creswell, J., (1994): "Research Design; Qualitative and Quantitative approaches": SAGE Publications.

Dunning, J., (1993), "Multinational enterprises and the global economy". London: Addison-Wesley.

Eitman, D.K., Stonhehill, A.K., \& Moffet, M.K., (2004), "Multinational Business Finance", 10 th $^{\text {th }}$ Edition, Published by Pearson Addison Wesley.

Eitman, D.K., Stonhehill, A.K., \& Moffet, M.K., (2007), "Multinational Business Finance", 11 $11^{\text {th }}$ Edition, Published by Pearson Addison Wesley.

Ferdows, K., (1997), "Making the Most of the Foreign Factories", Harvard Business Review, March-April, 73-88.

Gamble, J. (2003).. "Transferring human resource practices from the United Kingdom to China: the limits and potential for convergence", International Journal of Human Resource Management, 14(3): 369-387.

Ghoshal, S., \& Bartlett, C. (1990), "The Multinational Corporation as an Interorganizational Network", Academy of Management Review , $15(4), 603-625$.

Harvey, M., Speier, Ch. \& Novecevic, M. M., (2001), "A theory-based framework for strategic global human resource staffing policies and practices", International Journal of Human Resource Management, Vol. 12, No. 6, September 2001, 898-915.

Hofstede, G., (1980), "Motivation, Leadership and Organization: Do American Theories Apply Abroad?", In: Organizational Dynamics, 16 (4), 4-21.

Kanungo, R. N. \& Jaeger, A. M., (1990), "Introduction: The need for indigenous management in developing countries", In A. M. Jaeger \& R. N . Kanungo (Eds.), Management in Developing Countries. London: Routledge.

Keller, E. von (1989), "Comparative Management", In: Macharzina, K./Welge, M.K. (Hg.): Handwörterbuch Export und internationale Unternehmung. Stuttgart, 231-241.

Kostova, T., (1999), "Transnational transfer of Strategie organizational practices: A contextual perspective", Academy of Management Review, 24(2), 308-32.

Laurent, A., (1983), "The cultural diversity of Western conceptions of management", International Studies of Management and Organization,1 3(1-2): 75-96.

Leat, M . \& El-Kot, G., (2007), "HRM practices in Egypt: The influence of national context?", The International Journal of Human Resource Management, 18(1), 147- 158.

Madura, J., (2002), "International Financial Management", $7^{\text {th }}$ Edition, South-Western Educational Publishing.

Perlmutter, H.V. (1969) 'The Tortuous Evolution of the Multinational Corporation', Columbia Journal of World Business, 4: 9-18.

Rosenzweig, P. M. \& Nohria, N., (1994), "Influences on HRM practices in multinational corporations", Journal of International Business Studies, Vol. 25, Issue 2, pp: 229-251.

Saunders M., Lewis P., Thornhill A., (2009), "Research Methods for Business Students", FT-Prentice Hall, 5th Edition.

Schneider, S., (1988), "National vs. corporate culture: Implications for human resource management", Human Resource Management, 27, 231-246.

Silverthorne, C. P., (2005), "Organizational Psychology in Cross-Cultural Perspective", New York, NY: New York University Press.

Tayeb, M. H. (1998), Transfer of HRM practices across cultures: an American company in Scotland, International Journal of HRM, Vol. 9, Issue 2, pp: 332-358.

Teagarden, M.B. \& Von Glinow, M.A. (1997), 'Human Resource Management in Cross-cultural contexts: Emic Practices versus Etic Philosophies', Management International Review, 37(1): 7-20.

Trompenaars, F. (1993), "Riding the Waves of Culture: Understanding Cultural Diversity in Business", Nicholas Braeley Publishing, London.

Tung, R. L, (1987), "Expatriate assignments: Enhancing success and minimizing failure", Academy of Management Executive, Vol. 1, No. 2, 117-125.

Uruçi, E. \& Boriçi (Begani), A. (2008), "Globalization forms and the Albanian economy, foreign trade and FDIs", International Conference "Economic and Social Challenges and Problems, 2008", University of Tirana, Faculty of Economy, Tirana, Albania, December 11$13^{\text {th }} 2008$.

Wild, J. J., Wild, K. L., \& Han, J. C. Y., (2003), "International Business", 2nd Edition, Prentice Hall. 